\title{
Prevalence of Diabetes in Rural and Urban Population of Ludhiana (Punjab)
}

\author{
Karmjeet Kaur $^{1 *}$, Harpreet Kaur ${ }^{1}$, Kiran Bains ${ }^{1}$, Jaswinder K. Brar ${ }^{1}$, \\ Amarjeet Kaur ${ }^{2}$, Amrit Kaur ${ }^{3}$ and Davinder Singh ${ }^{4}$
}

\author{
${ }^{1}$ Department of Food and Nutrition, ${ }^{2}$ Department of Food Science and Technology, \\ ${ }^{3}$ Department of Maths, Stat and Physics, ${ }^{4}$ Department of Extension Education, Punjab \\ Agricultural University, Ludhiana, India \\ *Corresponding author
}

\section{Keywords}

Type 2 Diabetes mellitus, Prevalence, Fasting blood glucose, Rural, Urban

\section{Article Info}

Accepted: 04 October 2020 Available Online: 10 November 2020

\section{A B S T R A C T}

There is a noticeable increase in the number of individuals affected with diabetes mellitus and the trend is scheduled to grow in geometric proportions in the next couple of decades. The study was conducted to assess the prevalence of diabetes in Ludhiana district. The Information was collected through personal interview schedule using the especially structured schedule. The entire data was collected from 2014-2018. Fasting blood glucose was checked using standard methods. It was found that out of 880 total subjects, prevalence rate of diabetes was significantly higher among urban subjects (45\%) as compared to rural subjects $(38 \%)$. Significantly higher percentage of urban men had diabetes $(51 \%)$ as compared to rural men (37\%) while 39 per cent rural and $38 \%$ urban women had diabetes. Fasting blood glucose levels among rural and urban men ranged from 66-463 and 61-362 mg/dl with mean value of 135.22 and $140.57 \mathrm{mg} / \mathrm{dl}$, respectively. The corresponding values in case of women were $60-431$ and $64-388 \mathrm{mg} / \mathrm{dl}$ with mean value of 136.85 and $132.11 \mathrm{mg} / \mathrm{dl}$, respectively. The study concluded that the prevalence rate of diabetes was significantly higher among urban subjects (45 per cent) as compared to rural subjects (38 per cent) whereas the mean fasting blood glucose levels of rural diabetic and non-diabetic subjects were significantly higher as compared to urban subjects.

\section{Introduction}

WHO has reported that there is a noticeable increase in the number of individuals affected with diabetes mellitus and the trend is scheduled to grow in geometric proportions in the next couple of decades. WHO also predicts that the developing nations will suffer from this epidemic in the 21 st century. A noticiable increase has been seen in the prevalence of diabetes in both rural as well as urban Indians with the sharpest increase in southern India in the previous two decades. Although genetic susceptibility is involved in etiology of type 1 diabetes to a certain extent. There are certain other factors which play role in it. High incidents of type 2 diabetes in population is associated with cultural changes in the diets which were consumed previously and also with increasing obesity, especially android type obesity. It has been noticed in various population groups that, family history 
of the disease (type 2 diabetes) is an important risk factor. Diet and lifestylerelated conditions which cause obesity will clearly influence the risk of an individual and populations, developing Diabetes, who are susceptible to this condition. As it has been noticed that with a given BMI (Body mass index), Asian Indians have comparatively higher waist circumference, higher waist-hip ratios, more subcutaneous and visceral fat and more insulin resistance than European individuals. (McKeigue et al., 1991)

Wild et al (2004) has reported that globally the prevalence of the disease is predicted to double in number from 171 million in 2000 366 million in 2030 and the maximum increase will be seen in India. By 2030 the diabetes mellitus may go up to 79.4 million individuals in India, 42.3 million individuals in China and 30.3 million in United States.(Whiting et al., 2011).

Nowadays diabetes mellitus has become an important public health challenge. It is the major cause of death and disability across the world. There is an uncertain future in front of India in relation to the potential burden that diabetes may impose upon the country. IDF Diabetes atlas Ninth edition 2019 has reported that globally the prevalence of the disease in 2019 was 463 million (adults of age 20-79 years) is predicted to rise to 700 million in 2045. (IDF Diabetes Atlas Ninth edition 2019).India is one of the members of the seven countries of the IDF SEA (South East Asia) region. Globally 463 million people have diabetes and in the SEA region 88 million people have the disease; it could rise to 153 million by 2045 . India is at the second position after China with 77 million cases of Type 2 diabetes mellitus (T2DM).

Health care facilities such as available reliable screening methods and medications are easily available in the urban area, which are not commonly accessible to rural patients. There is an uneven distribution of health resources in the rural and urban areas, and along with this in the rural area, poverty may be multifaceted. Food insecurity, lower literacy rate, poor hygiene and sanitation and dominance of communicable diseases are more in the rural area. There is also a lack of counselling services. The distance to health services is also very long. Lesser and old health care facilities in the rural area to manage diabetes may affect their diabetic complications as compared to urban people (Khalil and George 2012). It shows that both local governments and policymakers are maybe underprioritising the approaching threat of diabetes mellitus (Anjana et al., 2011c). All these insufficiencies contribute towards an infrastructure that is not equipped to deal with diabetes screening, management and prevention.

Knowledge and awareness about diabetes are not adequate in India. Various diabetes education programmes are instantly needed both in rural and urban India. The presence of several diabetic complications is seen at the time of clinical diagnosis of diabetes. It is the major reason behind the recommendations for screening for type 2 diabetes (Mohan et al 2005) (Manjula et al., 2016).

Regarding dietary habits, high intake of sugar (traditional sources as well as sugarsweetened beverages) has been found in the Indian population (Gulati and Misra 2014). Along with that Asian Indians consume fewer fruits and vegetables as compared to south Asian countries (Goyal and Yusuf, 2006). Besides this, excessive intake of refined cereals e.g. polished white rice has been found to elevate the chances of getting type 2 diabetes (Mohan et al., 2016). The physical activity level of Asian Indians has been found lower as compared to other communities (Anjana et al., 2016). Though there is an 
increased prevalence of diabetes within the country but there is no nationwide and very few multi-centric studies being conducted on assessing the prevalence of diabetes mellitus and its complications. The studies which have been conducted may also be prone to some potential error because of the heterogeneity of the Indian population with respect to ethnicity, culture, socio-economic settings, mean that the expectation of regional results may not give accurate estimates for the entire country. However, there is a trend of diabetes prevalence that is related to the geographical distribution of disease in India. Keeping the above discussion in mind the current study was carried out to assess the prevalence of diabetes mellitus in Ludhiana.

\section{Materials and Methods}

The present study was aimed to assess the prevalence and determinants of diabetes mellitus

\section{Selection of the Subjects}

The sampling design used for the study was 30 cluster multi-stage sampling. A total of 30 locations from Ludhiana district were selected targeting adult men and women. In the next stage of sampling 12 blocks of Ludhiana district were selected. From each block two villages (total of 24 villages) and 6 locations from the urban area were selected in order to have a total random sample size of 880 subjects in the age group $\geq 20$ years, representing the rural and urban areas of Ludhiana.

\section{Development of interview schedule}

A well-structured questionnaire-cum interview schedule was developed to elicit the general information, socio-economic status of the subjects. The preliminary interview schedule was pre-tested to ensure the validity of questionnaire. Thereafter, necessary modifications were incorporated. The modified questionnaire was used for the study.

\section{Collection of data}

The Information was collected through personal interview schedule using the especially structured schedule. The entire data was collected from 2014-2018.

\section{General Information}

Participants were recruited via door to door survey as well as the health camp approach. Local panchayats and village heads were consulted and permission was obtained to carry out the study. Informed verbal consent was obtained from all research participants prior to enrollment.

Participants then completed a brief survey form in which basic demographic information related to age, caste, religion, size and type of family, occupation, income and education of subjects were collected through personal interview technique.

\section{Measurement of fasting blood glucose}

In order to check the blood glucose measurements, participants were requested to attend the survey early in the morning, after an overnight fast of 8- 12 hours. Fasting capillary blood glucose was measured using a glucose meter (ACCU-CHECK ${ }^{\circledR}$ Active). Diabetes was defined on fulfilment of criteria laid down by the WHO consultation group report and international diabetes federation IDF (WHO, 2006), Diabetes was diagnosed on plasma fasting blood glucose $\geq 126 \mathrm{mg} / \mathrm{dl}$ and known cases of type 2 diabetes mellitus. Prediabetes was diagnosed on plasma fasting blood glucose $100 \mathrm{mg} / \mathrm{dL} \quad(5.6 \mathrm{mmol} / \mathrm{L})$ to $125 \mathrm{mg} / \mathrm{dL}$ (6.9mmol/L) (impaired fasting glucose). 


\section{Ethical issues}

This study was conducted according to the guidelines laid down in the Declaration of Helsinki and all procedures involving research study participants were approved by the Ethical Committee of Punjab Agricultural University. Informed consent was obtained from all subjects.

\section{Results and Discussion}

The present study was aimed to assess the prevalence, determinants of diabetes mellitus in Ludhiana district. Study was designed to conduct a survey in 30 locations of Ludhiana.

Eight hundred and eighty respondents were interviewed and surveyed. Out of total, 273 men and 391 women were from rural areas while 114 men and 102 women were from urban area, respectively to assess general information, anthropometric status, socioeconomic status, eating habits, family history of diabetes and physical activity pattern of the subjects. The target population was 40-60 years but individuals from other age groups who were interested in the study were also included to cover wide range of age that is $\geq 20$ years.

\section{General information of the study subjects}

\section{Age profile of the subjects}

Data in Table 1 reveals the general information of the study population. Majority of the rural men i.e. about 35 and 34 per cent were from the age group of 40-49 years and 50-59 years, respectively. In urban area, majority ( 32 per cent) of the men were in the age group of 50-59 years, followed by 28 per cent in the age group of $\geq 60$ years. It was observed that in case of rural women, 35 per cent women belonged to the age group of 4049 years and 28 per cent were in the age group of 50-59 years. In urban areas, majority of the women were in the age group of $\geq 60$ years (29 per cent) whereas 28 and $25 \%$ urban women were in the age group of 40-49 years and 50-59 years, respectively.

\section{Marital status}

Regarding the marital status of the study population, majority of the rural and urban men (97 and 98 per cent, respectively) were married. Similarly in case of women, 94 per cent rural and 96 per cent urban women were married.

\section{Caste}

Majority of the study subjects were from general category. In rural area 74 per cent men belonged to general caste and 26 per cent were from schedule caste (SC). The corresponding values in urban area were 74 and 26 per cent, respectively. Similarly in case of women, 61 per cent of the women were from general caste and 39 per cent were from SC category. Whereas in urban area 59 per cent women belonged to general category and 41 per cent women belonged to schedule caste category.

\section{Religion}

In rural area, majority of the study subjects (96 per cent) were Sikhs, 3 per cent men were Hindus and only small percentage (1 per cent) was of Muslims. Whereas in urban area (49 per cent) subjects belonged to Hindu religion and (49 per cent) to Sikh religion and only 2 per cent belonged to Muslim religion. In case of women, majority of the rural women belonged to Sikh religion (97 per cent) and only 3 per cent rural women belonged to Hindu religion. On the other hand in urban area 60 per cent of the urban women belonged to Hindu religion and 40 per cent women belonged to Sikh religion. 


\section{Type of family}

In the rural area 51 per cent men had nuclear family system and 49 per cent had joint family system. Whereas in urban area the percentage of men living in nuclear family system was higher (55 per cent) as compared to joint family system (45 per cent). In case of women, 52 per cent rural women were living in nuclear families and 48 per cent women had joint family system. Whereas the urban population of surveyed women were equally distributed in nuclear and joint family system.

\section{Family composition}

Data showed that majority of the rural men (57 per cent) had 5-8 family members, 34 per cent rural men had up to 4 family members and only 9 per cent subjects had family members more than eight. On the other hand, (46 per cent) of the urban men had family composition of up to 4 members and 5-8 members and only 8 per cent men had more than eight family members. In case of women majority of the rural women had family composition of 5-8 members. 37 per cent subjects had up to 4 family members and only 12 per cent women lived with more than eight family members. Whereas in urban area, 51 per cent women had 5-8 family members, 37 per cent urban women had up to 4 family members.

\section{Educational Status of the subjects}

Information pertaining to the educational status of the study population is presented in Table 1. It can be inferred that illiteracy rate was more among rural men and women (11 and 47 per cent) as compared to urban men and women ( 7 and 18 per cent, respectively). Majority of the rural and urban men had done matriculation (29 and 34 per cent, respectively). About 25 per cent rural men had the education level till middle class while 16 per cent urban men were educated upto senior secondary. Six per cent of urban men were post-graduated while no rural men had been educated to this higher degree.

In case of women, majority of the rural and urban women had received only primary education (21 and 20 per cent, respectively). Around 17 per cent rural women had the education level till middle class while 20 per cent urban women were educated upto higher secondary. In urban area, 9 and 7 per cent women had done graduation and post graduation respectively; where as no rural women had been educated to this degree.

Table.1 General information of the subjects

\begin{tabular}{|l|c|c|c|c|}
\hline \multirow{2}{*}{ Characteristics } & \multicolumn{2}{|c|}{ Men } & \multicolumn{2}{c|}{ Women } \\
\cline { 2 - 5 } & $\begin{array}{c}\text { Rural } \\
(\mathbf{n = 2 7 3})\end{array}$ & $\begin{array}{c}\text { Urban } \\
(\mathbf{n = 1 1 4})\end{array}$ & $\begin{array}{c}\text { Rural } \\
(\mathbf{n = 3 9 1})\end{array}$ & $\begin{array}{c}\text { Urban } \\
(\mathbf{n = 1 0 2})\end{array}$ \\
\hline Age (years) & & & & \\
\hline$<\mathbf{3 0}$ & $5(2)$ & $3(3)$ & $9(2)$ & $7(7)$ \\
\hline $\mathbf{3 0 - 3 9}$ & $18(7)$ & $12(11)$ & $47(12)$ & $10(10)$ \\
\hline $\mathbf{4 0 - 4 9}$ & $95(35)$ & $31(27)$ & $135(35)$ & $29(28)$ \\
\hline $\mathbf{5 0 - 5 9}$ & $92(34)$ & $36(32)$ & $110(28)$ & $26(25)$ \\
\hline $\begin{array}{c}\mathbf{2 6 0} \\
\text { Marital status }\end{array}$ & $63(23)$ & $32(28)$ & $90(23)$ & $30(29)$ \\
\hline Married & $266(97)$ & $112(98)$ & $369(94)$ & $98(96)$ \\
\hline Widowed & $6(2)$ & $0(0)$ & $22(6)$ & $1(1)$ \\
\hline
\end{tabular}




\begin{tabular}{|c|c|c|c|c|}
\hline Single & $1(0)$ & $2(2)$ & $0(0)$ & $3(3)$ \\
\hline \multicolumn{5}{|l|}{ Caste } \\
\hline General & 202(74) & $84(74)$ & $238(61)$ & $60(59)$ \\
\hline SC & $71(26)$ & $30(26)$ & $153(39)$ & $42(41)$ \\
\hline \multicolumn{5}{|l|}{ Religion } \\
\hline Hindu & $9(3)$ & $56(49)$ & $10(3)$ & $61(60)$ \\
\hline Sikh & 263(96) & $56(49)$ & 381(97) & $41(40)$ \\
\hline Muslim & $1(0)$ & $2(2)$ & $0(0)$ & $0(0)$ \\
\hline Christian & $0(0)$ & $0(0)$ & $0(0)$ & $0(0)$ \\
\hline \multicolumn{5}{|l|}{ Type of family } \\
\hline Nuclear & $138(51)$ & $63(55)$ & $202(52)$ & $51(50)$ \\
\hline Joint & 135(49) & $51(45)$ & $189(48)$ & $51(50)$ \\
\hline \multicolumn{5}{|l|}{$\begin{array}{l}\text { Family } \\
\text { Composition }\end{array}$} \\
\hline $\begin{array}{l}\text { Up to } 4 \\
\text { members }\end{array}$ & 93(34) & $53(46)$ & 144(37) & $38(37)$ \\
\hline 5-8 members & $155(57)$ & $52(46)$ & 199(51) & $52(51)$ \\
\hline$>8$ members & $25(9)$ & $9(8)$ & $48(12)$ & $12(12)$ \\
\hline \multicolumn{5}{|l|}{ Education } \\
\hline No education & $30(11)$ & $8(7)$ & $185(47)$ & $18(18)$ \\
\hline Primary & $58(11)$ & $15(13)$ & $82(21)$ & $20(20)$ \\
\hline Middle & $68(25)$ & 12(11) & $65(17)$ & $15(15)$ \\
\hline Matric & $80(29)$ & $39(34)$ & $44(11)$ & $13(13)$ \\
\hline $\begin{array}{l}\text { Higher } \\
\text { secondary }\end{array}$ & $22(8)$ & $18(16)$ & 15(4) & $20(20)$ \\
\hline Graduate & $15(5)$ & $15(13)$ & $0(0)$ & $9(9)$ \\
\hline Post graduate & $0(0)$ & $7(6)$ & $0(0)$ & $7(7)$ \\
\hline \multicolumn{5}{|l|}{ Occupation } \\
\hline Farmer & $210(77)$ & $9(7)$ & 0 & 0 \\
\hline Business & $8(3)$ & $56(49)$ & 0 & $21(21)$ \\
\hline Service & $17(6)$ & $24(21)$ & $10(3)$ & $7(7)$ \\
\hline Labour & $28(10)$ & $15(13)$ & $41(10)$ & $0(0)$ \\
\hline Home maker & $0(0)$ & $0(0)$ & $340(87)$ & $72(71)$ \\
\hline Retired & $10(4)$ & $11(10)$ & $0(0)$ & $0(0)$ \\
\hline \multicolumn{5}{|l|}{$\begin{array}{l}\text { Monthly income } \\
\text { (Rs.) }\end{array}$} \\
\hline$<5000$ & $0(0)$ & 0 & $14(4)$ & $0(0)$ \\
\hline 5000-10000 & $18(7)$ & $2(2)$ & 21(5) & $0(0)$ \\
\hline $10000-20000$ & $51(19)$ & $32(28)$ & $92(24)$ & $13(13)$ \\
\hline 20000-30000 & $182(67)$ & $60(53)$ & 208(53) & $56(55)$ \\
\hline$\geq 30000$ & $22(8)$ & $20(18)$ & $56(14)$ & $33(32)$ \\
\hline
\end{tabular}

Figures in parentheses represent percentages 
Table.2 Distribution of the subjects on the basis of blood glucose levels

\begin{tabular}{|c|c|c|c|c|c|c|c|c|c|c|}
\hline \multirow[t]{2}{*}{ Category } & \multirow{2}{*}{$\begin{array}{c}\text { Blood } \\
\text { glucose } \\
\text { levels } \\
\text { mg/dL }\end{array}$} & \multicolumn{3}{|c|}{ Men } & \multicolumn{3}{|c|}{ Women } & \multicolumn{3}{|c|}{ Total $(\mathrm{N}=\mathbf{8 8 0})$} \\
\hline & & $\begin{array}{c}\text { Rural } \\
(n=273)\end{array}$ & $\begin{array}{l}\text { Urban } \\
(n=114)\end{array}$ & Z- value & $\begin{array}{c}\text { Rural } \\
(n=391)\end{array}$ & $\begin{array}{c}\text { Urban } \\
(n=102)\end{array}$ & Z-value & $\begin{array}{c}\text { Rural } \\
(n=664)\end{array}$ & $\begin{array}{c}\text { Urban } \\
(n=216)\end{array}$ & Z-value \\
\hline Non diabetics & $<110$ & $124(45)$ & $41(36)$ & $1.71 *$ & $180(46)$ & $52(51)$ & $0.89^{\mathrm{NS}}$ & $304(46)$ & $93(43)$ & $0.70^{\mathrm{NS}}$ \\
\hline $\begin{array}{c}\text { Impaired fasting } \\
\text { glucose }\end{array}$ & $110-125$ & $48(18)$ & $15(13)$ & $1.07^{\mathrm{NS}}$ & $58(15)$ & $11(11)$ & $1.05^{\mathrm{NS}}$ & $106(16)$ & $26(12)$ & $1.40^{\mathrm{NS}}$ \\
\hline Diabetics & $>125$ & 101(37) & $58(51)$ & $2.53 * *$ & 153(39) & $39(38)$ & $0.17^{\mathrm{NS}}$ & $254(38)$ & $97(45)$ & $1.73 *$ \\
\hline
\end{tabular}

Figures in parenthesis are percentages.

*Significant at 10\%; **Significant at 5\%; *** Significant at $1 \%$ NS-Non Significant

Table.3 Fasting blood glucose levels of the study subjects

\begin{tabular}{|c|l|c|c|c|}
\hline \multicolumn{2}{|c|}{ Subjects } & \multicolumn{2}{c|}{ Fasting blood glucose (mg/dl) } & \multirow{2}{*}{ t -value } \\
\cline { 2 - 5 } & & Range & Mean \pm SE & \\
\hline \multirow{2}{*}{ Men } & Rural (n=273) & $66-463$ & $135.22 \pm 3.98$ & \multirow{2}{*}{$21.01^{*}$} \\
\cline { 2 - 5 } & Urban (n=114) & $61-362$ & $140.57 \pm 5.73$ & \\
\hline \multirow{2}{*}{ Women } & Rural (n=391) & $60-431$ & $136.85 \pm 3.51$ & \multirow{2}{*}{$17.81 *$} \\
\cline { 2 - 4 } & Urban (n=102) & $64-388$ & $132.11 \pm 6.31$ & \\
\hline
\end{tabular}

Fasting glucose level normal range $<110 \mathrm{mg} / \mathrm{dl}$

*Significant at $5 \%$ level

Table4 Prevalence of diabetes among the subjects in different age groups

\begin{tabular}{|c|c|c|c|c|c|c|c|c|}
\hline \multirow[t]{3}{*}{ Age, years } & \multicolumn{4}{|c|}{ Men } & \multicolumn{4}{|c|}{ Women } \\
\hline & \multicolumn{2}{|r|}{ Rural } & \multicolumn{2}{|r|}{ Urban } & \multicolumn{2}{|r|}{ Rural } & \multicolumn{2}{|c|}{ Urban } \\
\hline & $\mathbf{n}$ & Number (\%) & $\mathbf{n}$ & Number (\%) & $\mathbf{n}$ & Number (\%) & $\mathbf{n}$ & Number (\%) \\
\hline$<30$ & 3 & $0(0)$ & 2 & $1(50)$ & 5 & $3(60)$ & 4 & $0(0)$ \\
\hline 30-39 & 20 & $6(30)$ & 13 & $3(23)$ & 51 & $12(24)$ & 13 & $4(31)$ \\
\hline $40-49$ & 95 & $37(39)$ & 31 & $15(48)$ & 135 & $36(27)$ & 29 & $8(28)$ \\
\hline $50-59$ & 92 & $38(41)$ & 36 & $18(50)$ & 110 & $48(44)$ & 26 & $10(38)$ \\
\hline$\geq 60$ & 63 & $20(32)$ & 32 & $21(66)$ & 90 & $54(60)$ & 30 & $17(57)$ \\
\hline Total & 273 & 101(37) & 114 & $58(51)$ & 391 & 153(39) & 102 & $39(38)$ \\
\hline
\end{tabular}

Figures in the parenthesis represent percentages 
Fig.1 Distribution of men based on blood glucose levels
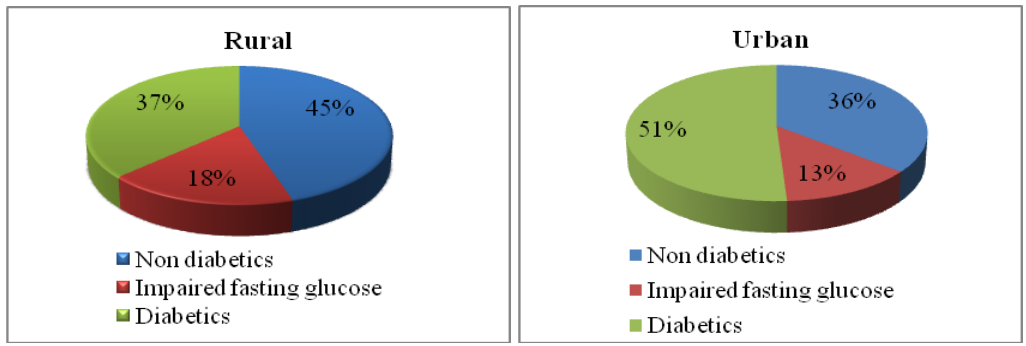

Fig.2 Distribution of women based on blood glucose levels
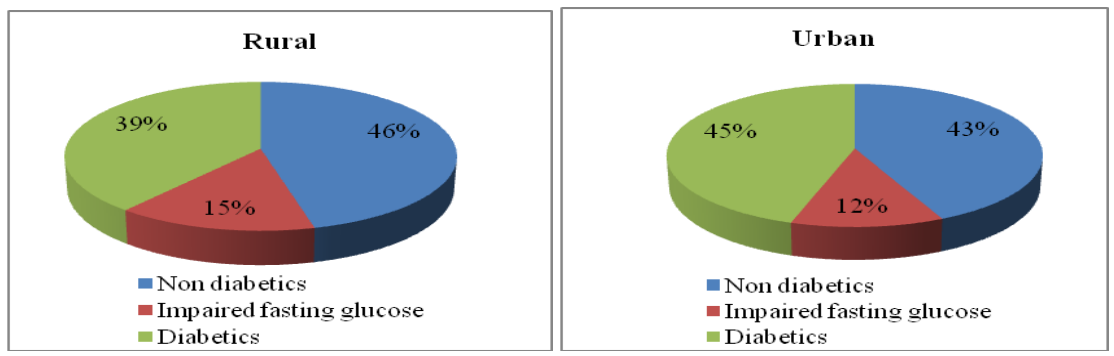

Fig.3 Mean fasting blood glucose levels of selected men

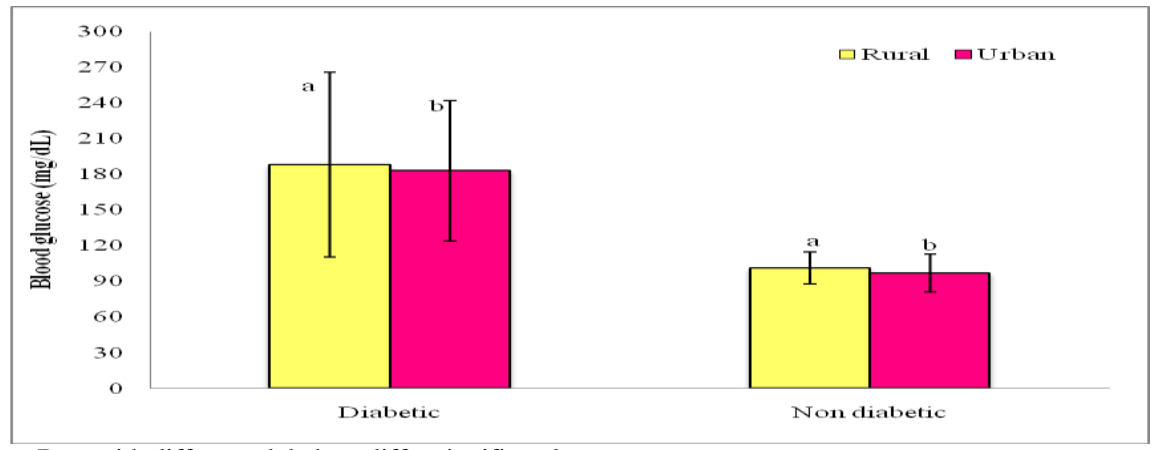

Bars with different alphabets differ significantly

Fig.4 Mean fasting blood glucose levels of selected women

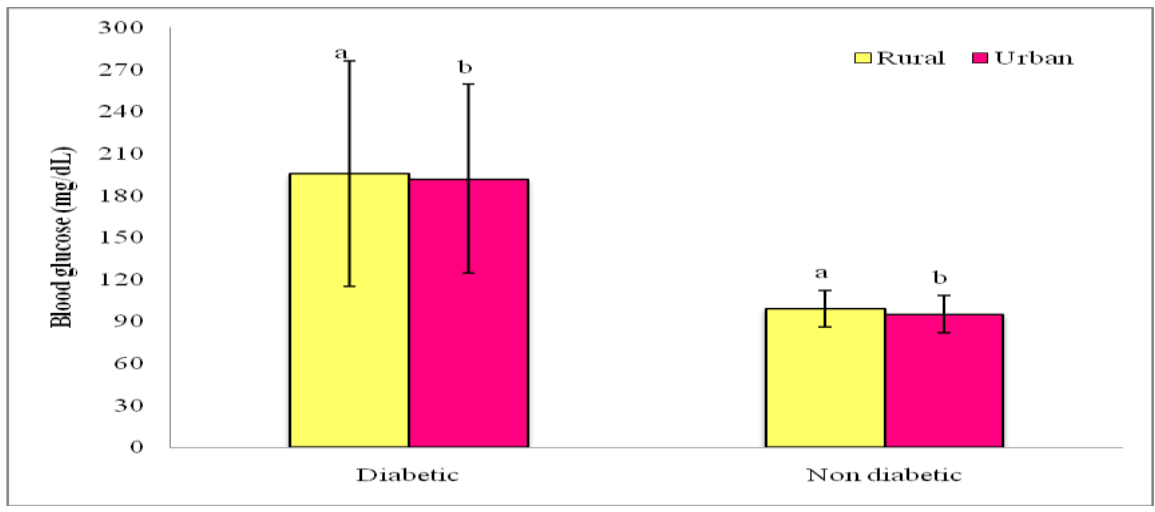

Bars with different alphabets differ significantly 


\section{Occupation}

Majority of the men in rural area were involved in farming (77 per cent) followed by 10 per cent as labourers, 6 per cent were in service sector and only 3 per cent were involved in business (Table 1). On the other hand, majority of the urban men were involved in business (49 per cent) followed by 21 per cent in service sector, 14 per cent belonged to labour category and 10 per cent were retired elders and only 7 per cent urban men were involved in farming.

For women, majority of the rural and urban women were home maker (87 and 71 per cent), respectively. This was followed by 10 per cent as labourers in rural women and 21 per cent of urban women were engaged in business.

\section{Monthly Income}

The subjects were classified under five different income groups. It is evident from the Table 1 that majority of the rural and urban men (67 and 53 per cent, respectively) had monthly income between Rs. 20-30,000. Around 8 per cent of rural men and 18 per cent of the urban men had monthly income $\geq$ Rs.30000 because of more opportunities of income like business and service in the urban area. Majority of the studied rural and urban women (53 and 55 per cent. respectively) had monthly family income range Rs.2000030000. Around 14 and 32 per cent rural and urban women had family income Rs. $\geq 30000$, respectively. Only 4 per cent rural women had monthly income less than Rs. 5000.

\section{Prevalence of diabetes}

The prevalence of diabetes in the study population both in rural and urban men and women are given in the Table 2 (Fig. 1 and 2).
Data revealed that out of 880 total subjects, prevalence rate of diabetes was significantly higher among urban subjects (45 per cent) as compared to rural subjects (38 per cent). Significantly higher percentage of urban men had diabetes (51 per cent) as compared to rural men (37 per cent) while 39 per cent rural and 38 per cent urban women had diabetes. Impaired fasting glucose was observed higher among rural men and women but the difference was non significant.

Studies done in India have reported a greater diabetes prevalence in urban area as compared to rural area (Ramachandran et al., 2010; Gupta and Misra, 2007). The Indian Industrial Population Surveillance Study evaluated the prevalence of diabetes at seven industrial sites in the country and reported a diabetes prevalence of $8 \%$ (Reddy et al., 2006). The Indian women's Health Study evaluated diabetes in middle-aged women of age 35-70 years, in different rural and urban locations of the country and reported diabetes in $2.2 \%$ rural and $9.3 \%$ urban women (Pandey et al., 2013). The India migration study reported diabetes in $13.5 \%$ urban, $9.3 \%$ rural and $14.3 \%$ migrant participants (Ebrahim et al., 2010).

Regional Studies have reported greater prevalence of diabetes in southern India as compared to north, east, and central India (Anjana et al., 2011 and Gupta et al., 2010). Gupta et al., (2014) have reported that regional differences in diabetes prevalence are related more to the Social Development Index (Banerjee et al., 2011) of the cities and not to the geography. The cities which have lower poverty indices and better social development indices have a greater prevalence of diabetes. It could be the reason for higher prevalence rates found in the current study because according to the Human Development Report 2004, Ludhiana tops the state in Human Development index. 
Fasting blood glucose levels of study subjects

Fasting blood glucose levels among rural and urban men ranged from 66-463 and 61-362 $\mathrm{mg} / \mathrm{dl}$ with mean value of 135.22 and 140.57 $\mathrm{mg} / \mathrm{dl}$, respectively (Table 3). The corresponding values in case of women were 60-431 and 64-388 with mean value of 136.85 and $132.11 \mathrm{mg} / \mathrm{dl}$, respectively. Fasting blood glucose values were found to be significantly higher in urban men than rural men, whereas in case of women these values were significantly higher in rural women than urban women. In comparison to the normal value of Fasting glucose level, the mean value was found to be higher than the normal level falls under the diabetes (Fig. 3 and 4).

Distribution of diabetic subjects rural as well as urban based on their age has been presented in the Table 4 . It was seen that the majority of the rural diabetic men $(41 \%)$ were in the age group 50-59 years, followed by 39 per cent in the age group 40-49 years while $(32 \%)$ of the diabetic men were in the age group $\geq 60$ years. Among urban subjects, majority of the diabetic men were in the age group $\geq 60$ years, followed by 50 per cent men in the age group of 50-59 years and 48 per cent in the age group of 40-49 years, respectively.

Among women, majority of the rural women were in the age group of $\geq 60$ years followed by 44 per cent women in the age group of 50 59 years and 27 per cent women in the age group of 40-49 years, respectively. Similar trend was observed among urban women, majority of the women were in the age group $\geq 60$ years, followed by 38 per cent women in the age group of 50-59 years and 28 per cent women in the age group of 40-49 years respectively. It is clearly evident that the prevalence of diabetes mellitus increases with age.
In conclusion has been found, out of 880 total subjects, prevalence rate of diabetes was significantly higher among urban subjects (45 per cent) as compared to rural subjects (38 per cent). Significantly higher percentage of urban men had diabetes (51 per cent) as compared to rural men (37 per cent) while 39 per cent rural and 38 per cent urban women had diabetes. The prevalence of diabetes mellitus was seen increasing with age in the study. Whereas impaired fasting glucose was observed higher in rural men and women but the difference was non significant. Fasting blood glucose levels among rural and urban men ranged from $66-463$ and $61-362 \mathrm{mg} / \mathrm{dl}$ with mean value of 135.22 and $140.57 \mathrm{mg} / \mathrm{dl}$, respectively. The corresponding values in case of women were 60-431 and 64-388 with mean value of 136.85 and $132.11 \mathrm{mg} / \mathrm{dl}$, respectively.

\section{References}

Anjana R M, Pradeepa R, Deepa M, Datta M, Sudha V, Unnikrishnan R, Bhansali A, Joshi S R, Joshi P P, Yajnik C S, Dhandhania V K, Nath L M, Das A K, Rao P V, Madhu S V, Shukla D K, Kaur T, Priya M, Nirmal E, Parvathi S J, Subhashini S, Subashini R, Ali M K and Mohan V (2011a). Prevalence of diabetes and prediabetes (impaired fasting glucose and/or impaired glucose tolerance) in urban and rural India: phase I results of the Indian Council of Medical Research-INdiaDIABetes (ICMR-INDIAB) study. Diabetologia 54:3022-3027.

Anjana R M, Pradeepa R, Deepa M, Datta M, Sudha V, Unnikrishnan R, Nath L M, Das A K, Madhu S V, Rao P V, Shukla D K, Kaur T, Ali M K and Mohan V (2011b). The Indian Council of Medical Research-India Diabetes (ICMRINDIAB) Study: Methodological Details. J Diabetes Sci Technol 5(4): 
906-14.

Anjana R M, Sudha V, Lakshmipriya N, Anitha C, Unnikrishnan R, Bhavadharini B, Mahalakshmi M M, Maheswari K, Kayal A, Ram U, Ranjani H, Ninov L, Deepa M, Pradeepa R, Pastakia S D, Malanda B, Belton A and Mohan V (2016) Physical activity patterns and gestational diabetes outcomes - The wings project. Diabetes Res Clin Pract 116: 25362.

Banerjee K (2011) Social development index 2010. In: Mohanty M, ed. India Social Development Report 2010. New Delhi: Oxford University Press, p259-93.

Ebrahim S, Kinra S, Bowen L, Andersen E, Ben-Shlomo Y, Lyngdoh T, Ramakrishnan L, Ahuja R C, Joshi P, Das S M, Mohan M, Davey Smith G, Prabhakaran D, Reddy K S; Indian Migration Study group (2010) The effect of rural-to-urban migration on obesity and diabetes in India: a cross sectional study. PLoS Med 7:e10000268.

Goyal A and Yusuf S (2006) The burden of cardiovascular disease in the Indian subcontinent. Indian J Med Res124: 235-44.

Gulati S and Misra A (2014) Sugar intake, obesity, and diabetes in India. Nutrients 6(12): 5955-74.

Gupta A and Mishra D K (2014) Food consumption pattern in rural India: A regional perspective. Journal of Economic \& Social Development 10(1) ISSN 0973 - 886X

Gupta R and Misra A (2007) Type-2 diabetes in India: regional disparities. $\mathrm{Br} J$ Diabetes Vasc Dis 7:12-16.

Gupta S K, Singh Z, Purty A J, Kar M, Vedapriya D R, Mahajan P and Cherian J (2010) Diabetes Prevalence and its Risk Factors in Rural Area of Tamil Nadu. Indian Journal of Community Medicine 35(3):396-399.
International Diabetes Federation. IDF Diabetes Atlas, 9th edition. Brussels, Belgium:2019. Available at: https://www.diabetesatlas.org

Khalil H and George J (2012) Diabetes management in Australian rural aged care facilities: A cross-sectional audit. Australas Med J 5(11): 575-80

Manjula D, Sasikumar N S, Sahu B and Babu G R (2016) Prevalence of Diabetes Mellitus in school teachers of Bengaluru RGUHS. National J Public Health 1(1): 13-21.

McKeigue P M, Shah B and Marmot M G (1991) Relation of central obesity and insulin resistance with high diabetes prevalence and cardiovascular risk in South Asians. Lancet 337(8738):382-6.

Mohan D, Raj D, Shanthirani C S, Datta M, Unwin NC, Kapur A and Mohan V (2005) Awareness and Knowledge of diabetes in Chennai-The Chennai urban rural epidemiology study [CURES-9]. $J$ Assoc Physicians India 53: 283-287.

Mohan V, Anjana R M, Gayathri R, Ramya Bai M, Lakshmipriya N, Ruchi V, Balasubramaniyam K K, Jakir M M, Shobana S, Unnikrishnan R, Krishnaswamy K, Henry J K and Sudha $\mathrm{V}$ (2016) Glycemic index of a novel high-fiber white rice variety developed in india-a randomized control trial study. Diabetes Technol Ther 18(3): 164-67.

Pandey R M, Gupta R, Misra A, Misra P, Singh V, Agrawal A, Dey S, Rao S, Menon V U, Kamalamma N, Devi K P, Revathi K and Sharma V (2013) Determinants of urban-rural differences in cardiovascular risk factors in middleaged women in India: a cross-sectional study. Int J Cardiol 163:157-62.

Ramachandran A, Ma R C and Snehalatha C (2010) Diabetes in Asia. Lancet 375:408-418.

Reddy K S, Prabhakaran D, Chaturvedi V, 
Jeemon P, Thankappan K R, Ramakrishnan L, Mohan B V, Pandav C $\mathrm{S}$, Ahmed F U, Joshi P P, Meera R, Amin R B, Ahuja R C, Das M S, Jaison T M (2006) Methods for establishing a surveillance system for cardiovascular diseases in Indian industrial populations. Bull World Health Organ 84:461-9.
(2011) IDF Diabetes atlas: Global estimates of the prevalence of diabetes for 2011 and 2030. Diabetes Res Clin Pract 94:311-21.

Wild S, Roglic G, Green A, Sicree R and King $H$ (2004) Global prevalence of diabetes-estimates for the year 2000 and projections for 2030. Diabetes Care 27(3):1047-53.

Whiting D, Guariguata L, Weil C and Shawj

\section{How to cite this article:}

Karmjeet Kaur, Harpreet Kaur, Kiran Bains, Jaswinder K. Brar, Amarjeet Kaur, Amrit Kaur and Davinder Singh. 2020. Prevalence of Diabetes in Rural and Urban Population of Ludhiana (Punjab). Int.J.Curr.Microbiol.App.Sci. 9(11): 106-117.

doi: https://doi.org/10.20546/ijcmas.2020.911.012 